\section{In Vitro Micropropagation for Maintenance of Mycoplasma-like Organisms in Infected Plant Tissues}

\author{
Assunta Bertaccini \\ Istituto di Patologia Vegetale, Università degli Studi, Bologna 40126, \\ Italy
}

\author{
Robert E. Davis and Ing Ming Lee \\ Microbiology and Plant Pathology Laboratory, Agricultural Research \\ Service, U.S. Department of Agriculture, Beltsville, MD 20705
}

\begin{abstract}
Additional index words. Chrysanthemum frutescens, Gladiolus sp., Hydrangea macrophylla, Catharanthus roseus, shoot culture, disease symptoms, dot hybridization, cDNA probe
\end{abstract}

\begin{abstract}
A collection of mycoplasma-like organisms (MLOs) was maintained in plant tissues micropropagated in vitro. MLO-infected plants included Chrysanthemum frutescens L. with chyrsanthemum yellows disease, Gladiolus sp. L. with "germ fins," Hydrangea macrophilla (Thunb.) DC. with virescence, Rubus fruticosus L. with rubus stunt, and periwinkle [Catharanthus roseus (L.) G. Don] singly infected by the following MLOs: Italian periwinkle virescence, chrysanthemum yellows, North American aster yellows, Italian periwinkle stunt, American periwinkle little leaf. Shoots micropropagated in vitro exhibited symptoms of little-leaf and/or abnormal proliferation of axillary shoots resulting in "witches' broom" appearance that resembled symptoms in grafttransmitted greenhouse-grown or naturally infected field-collected plants. These symptoms, typical of infection by MLOs, were not observed in micropropagated healthy shoots of the same plant species, and, compared with the healthy ones, varied with MLO strain and host plant species. Dot hybridizations with a nonradioactive cloned DNA probe provided evidence for the presence of MLOs in propagated tissues through serial subcultures.
\end{abstract}

Mycoplasma-like organisms (MLOs) are minute prokaryotes lacking cell walls associated with diseases in plants. More than 600 plant species around the world are known to be naturally infected by MLOs (Marwitz, 1990). MLOs are associated with some of the most destructive plant diseases, but knowledge about MLOs has been limited by our inability to isolate them in pure culture. Axenic cultures of MLOs have not been reported (Lee and Davis, 1986). For scientific investigation, MLOs must be maintained in living hosts. In nature, MLOs are maintained through a cycle of transmission involving insect vectors and plant hosts. In the laboratory, MLOs may be maintained in a plantinsect-plant cycle but are commonly sustained through inoculation of susceptible plants by grafting with compatible MLO-infected plant species. Catharanthus roseus is a congenial host for many, perhaps all, MLOS and is commonly used for maintenance of collections of MLO strains by grafting. In cases where transmission to $C$. roseus has

Received for publication 18 Nov. 1991. Accepted for publicatidn 6 May 1992. We gratefully acknowledge Anna Maria Ventura for excellent technical assistance. Research supported by $\mathrm{Na}$ tional Research Council of Italy, Special Project RAISA, Sub-project no. 2, Paper no. 368. The cost of publishing this paper was defrayed in part by the payment of page charges. Under postal regulations, this paper therefore must be hereby marked advertisement solely to indicate this fact. not been achieved, and where study of the MLO-plant interaction in a different plant species is to be investigated, plant species other than $C$. roseus can be used to maintain MLOs. Maintenance of a collection of MLOs in whole plants necessitates precautions against unintentional cross-contamination of strains and against vector transmission leading to escape of exotic MLO strains. Thus, plants must be grown under special quarantine and insect control regimes that can require considerable greenhouse or growth chamber space. Moreover, MLO strains in a collection may require various temperature regimes for optimum maintenance.

Tissue culture of MLO-infected plants offers an advantageous alternative for maintenance of MLO collections. Maintenance of MLOs in serially subcultured plant callus has not been successful, undoubtedly because of lack of formation of new phloem sieve cells with direct connection with preexisting sieve elements, the cell type to which the parasitic MLOs are believed to be restricted in infected plants (Jacoli and Ronald, 1974; Mitsuhashi and Maramorosh, 1964; Petru et al., 1971). Shoot tip cultures are generally confined to naturally infected plant species that may require diverse media for successful in vitro culture (Cousin et al., 1990; Sears and Klomparens, 1989). In this report, we describe maintenance of a collection of MLO strains by in vitro propagation of infected $C$. roseus, a "universal" host for MLOs, as well as several other plant species infected by MLOs, using a single culture medium.

MLO-infected plants for this study were derived from a strain collection maintained by grafting of whole plants grown in a greenhouse, or naturally inoculated symptomatic plants collected in the field in Italy or in the United States. Symptoms included virescence of flowers, proliferation of axillary shoots resulting in a "witches' broom" or "germ fins" (Albouy, 1966) appearance, stunting, and abnormally small leaves (littleleaf symptom). Plant species, MLO strains, and location of MLO strain origin are provided (Table 1). The presence of MLOs in the plants was demonstrated by one or more methods, including electron microscopy (Bertaccini et al., 1988; Marani et al., 1977),

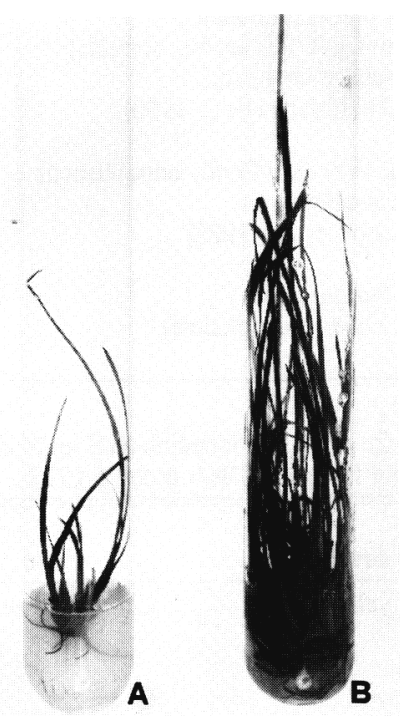

Fig. 1. (A) Healthy Gladiolus sp. shoots in tissue culture; (B) shoots infected by MLO showing the typical "germ fins" symptoms. The presence of MLO increased the proliferation rate.

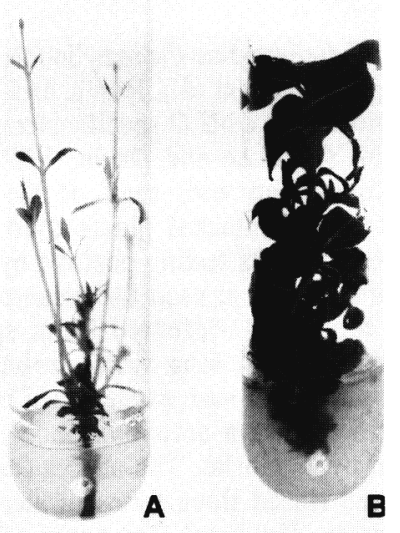

Fig. 2. Catharanthus roseus shoot infected by Italian periwinkle stunt in culture (A). The elongation of the stem and small leaves are characteristic symptoms induced by this mycoplasmalike organism. (B) Healthy $C$. roseus as control. 
Table 1. Mycoplasma-like organisms (MLOs) maintained by in vitro culture of diseased shoots.

\begin{tabular}{|c|c|c|}
\hline MLO strain (reference) & Geographic origin & $\begin{array}{l}\text { Host plant used } \\
\text { for in vitro propagation }\end{array}$ \\
\hline Aster yellows (Lee and Davis, 1988) & Maryland & Catharanthus roseus \\
\hline \multicolumn{3}{|l|}{ Chrysanthemum yellows } \\
\hline \multirow[t]{2}{*}{ (Conti and Mela, 1987) } & Liguria, Italy & C. roseus \\
\hline & & Chrysanthemum frutescens \\
\hline \multicolumn{3}{|l|}{ Italian periwinkle virescence } \\
\hline (Davis et al. 1992) & Emilia-Romagna, Italy & C. roseus \\
\hline \multicolumn{3}{|l|}{ Sweetpotato witches' broom } \\
\hline (Green et al., 1989) & Taiwan & C. roseus \\
\hline \multicolumn{3}{|l|}{ American periwinkle little leaf } \\
\hline (Davis et al., 1990) & Connecticut & C. roseus \\
\hline \multicolumn{3}{|l|}{ Potato witches' broom } \\
\hline (Deng and Hiruki, 1990) & Canada & C. roseus \\
\hline \multicolumn{3}{|l|}{ "Germs fins" of Gladiolus sp. } \\
\hline (Bellardi et al., 1985) & Emilia-Romagna & $\begin{array}{l}\text { GIadiolus sp. } \\
\text { 'Rose Suprème' }\end{array}$ \\
\hline \multicolumn{3}{|l|}{ Hydrangea sp. virescence } \\
\hline (Pisi and Bellardi, 1990) & Emilia-Romagna & Hydrangea macrophylla \\
\hline \multicolumn{3}{|l|}{ Italian periwinkle stunt } \\
\hline (Davis and Bertaccini, unpubl.) & Emilia-Romagna & C. roseus \\
\hline \multicolumn{3}{|l|}{ Flavescence dorée-like } \\
\hline MLO (Refatti et al., 1990) & $\begin{array}{l}\text { Friuli-Venezia } \\
\text { Guilia, Italy }\end{array}$ & C. roseus \\
\hline Rubus stunt (M. Conti, unpublished) & Piemonte, Italy & Rubus fruticosus \\
\hline \multicolumn{3}{|l|}{ Apple proliferation } \\
\hline (Carraro et al., 1988) & $\begin{array}{l}\text { Friuli-Venezia } \\
\text { Giulia }\end{array}$ & C. roseus \\
\hline \multirow{2}{*}{$\begin{array}{l}\text { Plum leptonecrosis } \\
\text { (R. Osler, unpublished) }\end{array}$} & & \\
\hline & $\begin{array}{l}\text { Friuli-Venezia } \\
\text { Giulia }\end{array}$ & C. roseus \\
\hline
\end{tabular}

Table 2. Dot hybridization tests on total DNA extracted from in vitro-propagated MLO-infected plants using the MLO-DNA probe pAY22.

\begin{tabular}{llcc}
\hline \hline MLO strain & \multicolumn{1}{c}{ Host plant } & No. shoots tested ${ }^{2}$ & $\begin{array}{c}\text { Positive } \\
\text { hybridizations }\end{array}$ \\
\hline Aster yellows & Catharanthus roseus & (S) 7 & 7 \\
Chrysanthemum & & (A) 2 & 2 \\
yellows (CY) & C. roseus & (S) 11 & 9 \\
CY & Chrysanthemum & (A) 4 & 3 \\
Germs fins & frutescens & (S) 3 & 2 \\
& Gladiolus sp. & (A) 2 & 1 \\
Italian periwinkle & 'Rose Suprème' & (S) 6 & 0 \\
viresccncc & C. roseus & (A) 1 & 5 \\
Hvdrangea & & (S) 6 & 3 \\
virescence & Hydrangea macrophyla & (A) 4 & 4 \\
& & (S) 4 & 0 \\
\hline
\end{tabular}

${ }^{2}(\mathrm{~S})$, Symptomatic plantlets; (A), asymptomatic plantlets.

DAPI (4',6-diamidino-2-phenylindole 2HCl) staining (Sinclair et al., 1989), and dot hybridization using a MLO-specific cloned DNA probe pAY22 (Lee and Davis, 1988). This clone hybridized with most of the MLOs present in the infected plants used in this work. Only plants testing positive by one of these methods were used for tissue culture.

For each MLO-infected plant species, shoots 1 to $3 \mathrm{~cm}$ long were excised from mother plants and surface-sterilized by soaking for $5 \mathrm{~min}$ in a solution containing $9 \%$ calcium hypochlorite. The shoots (explants) were then rinsed three times in sterile distilled water. The basal 3 to $4 \mathrm{~mm}$ of five to 10 explants of each species was placed aseptically in a sterile Murashige and Skoog (1962) basal salts medium modified by the addition of (mg.liter $) 170 \quad \mathrm{NaH}_{2} \mathrm{PO}_{4}, 80$ adeninesulphate, and 0.4 thiamine $\mathrm{HC} 1$. The me- dium contained $3 \%$ sucrose, $0.7 \%$ agar, and $0.12 \mathrm{mg} N$-(phenylmethyl)-1 $H$-purine-6amine/liter (Bertaccini and Marani, 1986).

Tissue cultures were maintained in growth chambers at $24 \pm 1 \mathrm{C}$, under artificial illumination $\left(30 \mu \mathrm{mol} \cdot \mathrm{m}^{-2}-\mathrm{s}^{-1}\right)$ with a $16-\mathrm{h}$ photoperiod. Shoots were subcultured to fresh medium at intervals of 4 to 8 weeks for 14 months by either dividing the proliferated shoots or by cutting the nonproliferating elongated explants into $1-\mathrm{cm}$-long segments.

Micropropagated shoots that developed in tissue culture were tested for the presence of MLOs by nucleic acid dot hybridizations using MLO-specific cloned DNA probe pAY22 (Lee and Davis, 1988). For dot hybridizations, total nucleic acid was extracted from $0.3 \mathrm{~g}$ of tissue (Lee and Davis, 1988), spotted onto clean nitrocellulose membranes, and hybridized with the probe labeled with bio-

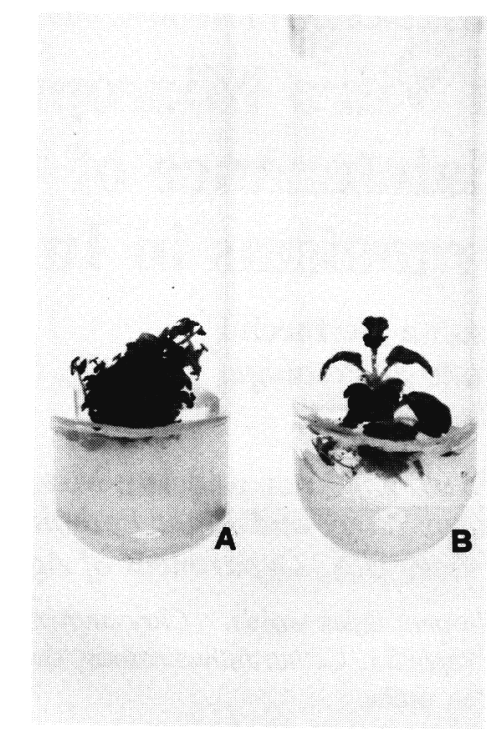

Fig. 3. Hydrangea macrophylla shoots after 4 weeks of tissue culture. The symptom of little leaf $(\mathbf{A})$ is typical of the virescence syndrome. (B) Healthy control shoot.

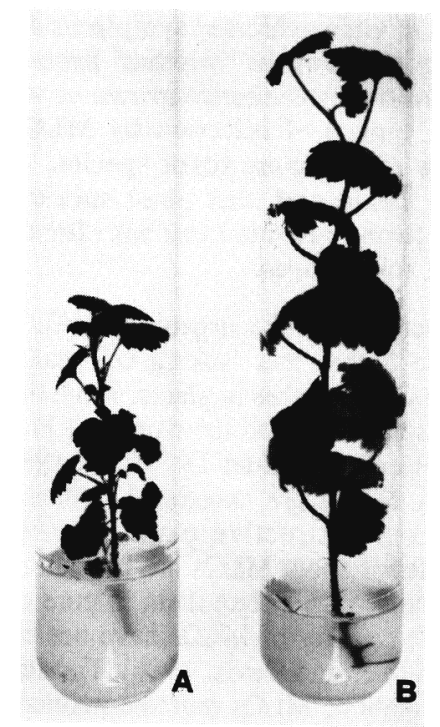

Fig. 4. Rubus fruticosus infected with rubus stunt (A) and healthy control (B). The proliferation of the shoots was obtained with microcuttings in vitro.

tin-7-dATP (Bethesda Research Laboratories, Gaithersburg, Md.). The hybridization was detected using the "BluGENE Nonradioactive Research Nucleic Acid Detection System" (Bethesda Research Laboratories).

The medium successfully supported growth of explants of all plant species tested. In the case of MLO-infected Gladiolus (Fig. 1), periwinkle (Fig. 2), and Chrysanthemum, axillary buds proliferated to form five to 10 shoots per explant; the healthy control shoots did not proliferate or only formed two to four shoots per explant.

Symptoms of virescence and witches' broom, characteristic of MLO infection from greenhouse-grown or field-collected plants, were observed in 37 of 50 shoots tested for maintenance of MLO infection after 14 
months of culture. Symptomatic and asymptomatic shoots from tissue cultures were tested to confirm the presence of MLOs. The results indicated the presence of MLOs in $80 \%$ of the shoots tested (Table 2).

Dot hybridizations revealed that MLOs could be detected in some asymptomatic shoots; however, MLOs were occasionally not detected in symptomatic shoots using the same techniques. For example, six shoots arising from subcultures of chrysanthemum and periwinkle infected by chrysanthemum yellows did not express obvious symptoms of infection, but MLOs were detected in four by dot hybridizations (Table 2). These results agree with previous reports of in vitro culture of MLO-infected evening primrose (Oenothera hookeri L.) and poplar (Populus $a b b a$ L.); adventitious shoots formed from side shoots associated with callus were asymptomatic (Cousin et al., 1990; Sears and Klomparens, 1989). In the present work, the production of shoots from callus was observed from only healthy and MLO-infected C. frutescens. A small amount of callus formed at the base of MLO-infected and healthy periwinkle shoots where the tissues were in direct contact with the medium, but no shoots were evident.

In the case of healthy and MLO-infected Hydrangea and Rubus (Figs. 3 and 4), the medium used permitted the survival of explants for 10 subcultures. Although shoots of Hydrangea explants did not elongate, shoots of Rubus did, and 1-cm-long microcuttings were used for subcultures. The optimum conditions to maintain and induce proliferation of these explants remain to be determined.

Small corms from infected Gladiolus were produced after the shoot proliferation stage. Corms were removed from cultures, stored at $4 \mathrm{C}$ for 2 weeks, surface-sterilized, and placed in fresh medium to allow growth of new shoots; $80 \%$ of these cormlets produced shoots with symptoms of germ fins.

The rate of shoot proliferation in tissuecultured periwinkle varied with strain of MLO. For example, periwinkle infected with the Italian periwinkle virescence MLO exhibited a low rate (two to four shoots per explant) of shoot proliferation when compared with periwinkle infected by the chry- santhemum yellows MLO (10 to 20 shoots per explant).

The maintainence of MLO strains through tissue culture of diseased Gladiolus, $\mathrm{Hy}$ drangea, Chrysanthemum, Rubus, or C. roseus can present a useful way to preserve a collection of living MLO strains for studies of MLO-plant interactions that may lead to an understanding of MLO pathogenicity. The maintenance of tissue-cultured, MLO-infected plant material also offers a useful means for exchanging MLO strains among laboratories, especially since axenic culture of plant pathogenic MLOs has not been possible.

\section{Literature Cited}

Albouy, J. 1966. Le problème des "germs fins" du glaieul. Ann. Epiphyt. 17:81-91.

Bellardi, M.G., V. Vicchi, and A. Bertaccini. 1985. Micoplasmosi del gladiolo. Inf. tore Fitopatol. 1:35-39.

Bertaccini, A. and F. Marani. 1986. BYMV-free clones of eight gladiolus cultivars obtained by meristem-tip culture. Acta Hort. 177:299-308.

Bertaccini, A., F. Marani, and S. Rapetti. 1988. Phyllody and virescence in ranunculus hybrids. Acta Hort. 234:123-128

Carraro, L., R. Osler, E. Refatti, and C. Poggi Pollini. 1988. Transmission of the possible agent of apple proliferation to Vinca rosea by dodder. Riv. Patol. Vegetale S IV. 24:43-51.

Conti, M. and L. Mela. 1987. Il giallume della margherita (Chrysanthemum frutescens) micoplasmosi tipica della riviera ligure. Dif. Piante 10:171-178.

Cousin, M.T., J. Roux, N. Millet, and M.F. Michel. 1990. Maintenance of MLOs (mycoplasma-like organisms) on Populus alba micropropagation. J. Phytopathol. 130:17-23.

Davis, R.E., I.M. Lee, SM. Douglas, and E.L. Dally. 1990. Molecular cloning and detection of chromosomal and extrachromosomal DNA of the mycoplasmalike organism (MLO) associated with little leaf disease in periwinkle $\mathrm{C} \mathrm{Ca}$ tharanthus roseus. Phytopathology 80:789-793.

Davis, R.E., E.L. Dally; A Bertaccini, R. Credi, I.M. Lee, R. Osler, L. Carraro, and M. Barba. 1992. Cloned DNA probes for specific detection of Italian periwinkle virescence mycoplasmalike organism (MLO) and investigation of genetic relatedness with other MLOs. Phytopath. Medit. 31:5-12.

Deng, S. and C. Hiruki. 1990. The use of cloned DNA probes for diagnosis of noncultivable plant mollicutes. Proc. Jun. Acad.. Ser. B. 66:58-
Green, S.K., C.Y. Luo, and D.R. Lee. 1989. Elimination of mycoplasmalike-organisms from witches' broom infected sweet potato. J. Phytopathol. 126:204-212.

Jacoli, G.G. and W.P. Ronald. 1974. Electron microscopic studies of plant tissue cultures infected with the aster yellows disease. J. Ultrastruct. Res. 46:342.

Lee, I.M. and R.E. Davis. 1986. Prospects for in vitro culture of plant-pathogenic mycoplasmalike organisms. Annu. Rev. Phytopathol. 24:339-354.

Lee, I.M. and R.E. Davis. 1988. Detection and investigation of genetic relatedness among aster yellows and other mycoplasmalike organisms using cloned DNA and RNA probes. Mol. PlantMicrobe Interact. 1:303-310.

Marani, F., A.M. Pisi, and A. Bertaccini. 1977. The association of mycoplasma-like bodies with Rubus stunt disease. Phvtopath. Medit. 16:150153.

Marwitz, R. 1990. Diversity of yellows disease agents in plant infections. Zentralbl. Bakteriol. (Suppl.) 20:431-434.

Mitsuhashi, J. and K. Maramorosh. 1964. Inoculation of plant tissue culture with aster yellows virus. Virology 23:277-279.

Murashige, T. and F. Skoog. 1962. A revised medium for rapid growth and bioassays with tabacco tissue cultures. Physiol. Plant. 15:474497.

Petru, E., J. Limbert M. Ulrychova, and J. Break. 1971. Growth and infectivity of callus cultures of tomato plants infected with a mycoplasma disease-potato witches' broom. Biol. Plant. 17:352-356

Pisi, A. and M.G. Bellardi. 1990. Virus diseases of ornamental shrubs. IV. Electron microscopy study of Mycoplasma-like organisms (MLO) and Hydrangea ring spot virus (HRSV) infecting Hydrangea macrophylla. Phytopathol. Medit. 29:59-63.

Refatti, E., R. Osler, L. Carraro, and F. Pavan. 1990. Natural diffusion of flavescence doréelike disease in north-east Italy. Intl. Council for Study of Virus \& Virus Dis. Grapevine, 10th meeting Volos, Greece, 3-7 Sept. 1990. p, 21.

Sears, B.B. and K.L. Klomparens. 1989. Leaf tip cultures of the evening primrose allow stable, aseptic culture of mycoplasma-like organisms. Can. J. Plant Pathol. 11:343-348.

Sinclair, W.A., R.J. Iuli, A.T. Dyer, and A.O. Larsen. 1989. Sampling and hystological procedures for diagnosis of ash yellows. Plant Dis. 73:432-435 